\title{
Educational Environment and Indicators of Child Development
}

\author{
Vitaliy V. Rubtsov \\ Moscow State University of Psychology and Education, \\ Moscow, Russia \\ Irina M. Ulanovskaya \\ Psychological Institute of Russian Academy of Education, \\ Moscow, Russia
}

\section{Образовательная среда школы и показатели детского развития}

\author{
Виталий В. Рубцов \\ Московский государственный психолого-педагогический университет, \\ Москва, Россия \\ Ирина М. Улановская \\ Психологический институт Российской академии образования, \\ Москва, Россия \\ Corresponding author. E-mail: rubtsovvv@mgppu.ru
}

\begin{abstract}
The article presents the author's approach to the interpretation of the concept of the educational environment of the school, based on the activity theory of A. N. Leontyev and on learning activity theory of D. B. Elkonin - V. V. Davydov. Significant features of two types of educational environments - the developing educational environment and the environment based on traditional educational content - are highlighted. A broad diagnostic research into the indicators of cognitive, social and personal development of students of these two types of educational environments was carried out. The study involved 2,304 students in the 5 th and 9 th grades from 24 schools.

To assess cognitive development, data from two tests is used: CFT2 and the "Transposition" method (author A.Z. Zak). An original diagnostic procedure has been developed to distinguish the role of factors of biological maturation and the educational environment of a particular school in the process of cognitive development of students.

Several sources were used to diagnose the social aspects of student development. This is a sociometric test, analysis of interactions in the system "students-teacher," recorded in the course of observation at the lesson (based on the author's "scheme of lesson analysis" - authors I. M. Ulanovskaya, N. I. Polivanova, E. V. Vysotskaya) and content analysis of children's essays on the topic "My school."


Indicators of personal development of students were determined by the scale "selfassessment and level of aspiration" test and the test of school anxiety (A. Prihodjan).

All data was subjected to statistical and qualitative analysis. The results obtained showed a high efficiency of the developing educational environment in the cognitive development of students. This is an expected result, since the programs used in developing educational environment are aimed at developing theoretical thinking based on the development of special educational content and appropriate forms of organization of the learning process.

Our results showed that educational environment developing qualitatively changes the sociometric structure of the class, making it more psychologically comfortable for students, increases cognitive motivation and reduces educational anxiety, makes self-assessment and level of aspiration more differentiated.

Keywords: school educational environment; developing educational environment; traditional educational environment; diagnostics; cognitive development; social development; personal development

Аннотация. В статье представлен авторский подход к интерпретации понятия образовательной среды школы, основанный на теории деятельности А.Н. Леонтьева и учебной деятельности Д. Б. Эльконина-В. В. Давыдова. Выделены существенные особенности развивающей образовательной среды и среды, основанной на традиционном образовательном содержании. Проведена широкая диагностика показателей когнитивного, социального и личностного развития учащихся, обучающихся в этих двух типах образовательной среды. В исследовании участвовали 2304 учащихся 5-х и 9-х классов из 24 школ.

Для оценки когнитивного развития использовались данные двух тестов: CFT2 и методики «Перестановки» (автор А.З. Зак). Разработана оригинальная диагностическая процедура, позволяющая различить роль факторов биологического созревания и образовательной среды конкретной школы в процессе когнитивного развития учащихся.

Для диагностики социальных аспектов развития учащихся использовалось несколько источников. Это социометрический тест, анализ взаимодействий в системе «учащиеся - учитель», зафиксированных в процессе наблюдения на уроке на основе авторской схемы анализа урока (авторы И. М. Улановская, Н. И. Поливанова, Е. В. Высоцкая), и контент-анализ детских сочинений на тему «Моя школа».

Показатели личностного развития учащихся определялись по шкальной методике «Самооценка и уровень притязаний» и тесту школьной тревожности (А. Прихожан).

Все данные были подвергнуты статистическому и качественному анализу. Полученные результаты показали высокую эффективность развивающей образовательной среды в когнитивном развитии учащихся. Это ожидаемый результат, так как программа развивающего обучения направлена именно на развитие теоретического мышления на базе освоения особого учебного содержания и соответствующих форм организации учебного процесса. 
Наши результаты показали, что развивающая образовательная среда качественно изменяет социометрическую структуру класса, делая ее более психологически комфортной для учащихся, повышает познавательную мотивацию и снижает учебную тревожность, делает более дифференцированными самооценку и уровень притязаний.

Ключевье слова: образовательная среда школь; развиваюшая образовательная среда; традиционная образовательная среда; диагностика; когнитивное развитие; соииальное развитие; личностное развитие

Developing the concept of the educational environment was started with research into the provisions of the theory of activity (Leontyev, 1981) and the theory of learning activity (Davydov, 1996; Davydov, Slobodchikov, \& Zuckerman, 1992; Elkonin, 1974; Elkonin \& Davydov, 1962).

We define the educational environment as an integral qualitative characteristics of the school internal life (Rubtsov \& Polivanova, 2007; Rubtsov \& Ivoshina, 2002). It is determined by the goals that a precise school sets and achieves in its activity. It is manifested in the choice of tools (means) that help to achieve these goals. These tools include peculiar properties of educational content, lesson organization, type of teacher-student interaction, extracurricular school life, class design, evaluation and school marks, etc. And it leads to the personal, social and cognitive development of students. We identified and described seven types of school educational environment and showed their developing potential (Rubtsov \& Ulanovskaya, 2010; Ulanovskaya, Polivanova, \& Ermakova, 1998). All these types of school educational environment are present in current educational practices. But in general, two educational paradigms should be distinguished. They represent different approaches to the problem of dependence between the processes of education and psychological development. In general, we can distinguish traditional teaching-learning paradigm and developing teaching-learning paradigm (developing educational environment).

Traditional teaching-learning paradigm is based on the principles of teacher's transmission of knowledge and its reproduction by students. Usually they also include skills as an object of transmission. Educational technologies based on the principles of transmission provoke mostly reproduction abilities of students (including simple cognitive stereotypes of perception, memory and thinking and complicated personal stereotypes of social behavior). In this paradigm creative and productive abilities of students, their personal features develop spontaneously.

The other approach is based on construction of special educational programs and organization of "learning to learn" situations (engineering of learning activity). This engineering is based on the theory of learning activity (D. Elkonin, V. Davydov) in the aspect of determination and organization of the learning content. Educational environment includes:

- creation of learning conditions in which a student can find out new interests and implement new creative abilities; 
- conditions for complex development of different abilities and personal features (physical, emotional, cognitive, personal) depending on individual peculiarities of students.

Knowledge and skills in the content of this approach are not any more the goal of education. They are just the means of development. Social positions of teacher and students also undergo changes: a student becomes a teacher's partner in educational interaction. A teacher now orientates not only on the problems of acquisition of knowledge, he becomes an organizer of learning situations based on interaction and cooperation with students.

Thus, developing educational environment is based on both students' and teachers' opportunity to become a subject of one's own development as a partner in the system "students-teacher." Apart from a traditional subject-object type of interaction this system must acquire a subject-subject type of interaction so that each of the participants becomes a condition and a means of development of the others. One of the necessary steps is formation of a reflective position of both a teacher and students towards each other.

It means that relations between didactic and psychological components of learning process organization change. Priority is shifted from didactics to psychology. Of course, it doesn't mean that teaching-learning activity must be implemented by psychologists instead of teachers. But it means that working out of the learning programs and implementation of these programs in a system of lessons must, first and foremost, correspond to the purpose of students' psychological development. And the didactic content must be used as a means of cognitive, personal, art, physical development.

In general, the main features of developing educational environment are:

- acquisition of skills and knowledge is no more treated as the main goal of education but as a means of development of child's abilities;

- a traditional subject-object type of teacher's influence over students' changes to co-action, cooperation, in which a teacher and students become partners in joint activity;

- developing education lays stress on psychological substantiation of teachinglearning activity, changes traditional relations between didactics and psychology, uses new psycho-didactic (instead of traditional didactic) criteria in construction of learning situations. Psycho-didactics means priority of psychological laws of development in construction of educational technologies (Davydov \& Rubtsov, 1995; Elkonin \& Davydov, 1962; Rubtsov \& Polivanova, 2007).

Modern tendencies in educational paradigms' development (from traditional towards developing) make it actual to solve problems of projecting and modeling of educational environments, on the one hand, and of evaluating developing effectiveness of existing educational environments, on the other. This second aspect (psycho-didactic expertise of existing educational environments) is the main subject of this article. 


\section{Research Hypothesis. Diagnostic Procedures and Methods}

The research hypothesis: the characteristics of cognitive, social and personal development of students are determined by the quality of the school's educational environment.

The expertise of educational environments of different schools was held using two groups of procedures:

1) procedures for (a) determination of a type of educational environment and (b) qualitative description of specific features of its implementation in a precise school;

2) procedures for evaluation of developmental effectiveness of school educational environment. These procedures and their results will be the subject of analysis in this article.

A set of procedures for evaluation of developmental effectiveness consists of three groups of methods.

The first group of methods deals with characteristics of thinking and cognitive processes. It was based on comparison of two tests. The first test permits to evaluate basic intellectual abilities that do not depend on the content of education or the type of organization of the teaching-learning activity. The second test evaluates the level of development of specific thinking operations that appear and function in a process of learning (Zak, 2019a, 2019b). We treated them as indicators of learning activity organization effectiveness. Comparison of the results in both tests permits to detect and evaluate the influence of the specific features of educational environment of a concrete school on development of students' cognitive abilities.

Basic intellectual abilities were detected using CFT2 test. This test uses nonverbal graphic material, differentiated in difficulty. Capacities, demonstrated by students in this test, are treated as inner (their own) ones. Briefly we shall call them "natural intellect."

Qualitative evaluation of thinking processes, connected with students' participation in teaching-learning activity, was based on diagnostic procedure named "Transposition" (Zak, 2019b).

In "Transposition" test the tasks are organized in a way that permits to evaluate cognitive activity based on a criterion of integral planning in problem solving. The test consists of 20 tasks. Each of them includes an initial position of graphic elements, a fixed number of mental transformations (from 1 to 5 ) and a sample of result position of elements. The number of problems solved correctly permits to evaluate the level of integral planning in problem solving. Each level is characterized by empirical or theoretical way of problem solving, depth and quality of analysis, content reflection.

The second group of methods deals with evaluation of social development (From joint activity..., 2018; Polivanova, Rivina, \& Ulanovskaya, 2017). We analyzed two groups of data: "objective" data showed real relations between students in class and between students and teachers and "subjective" data reflects the students' attitudes towards their educational environment.

Relations between students were studied with the help of sociometrical procedure, that included general, business and emotional criteria. Its results permit to evaluate level 
of adaptation of each student in the systems of business and emotional relations in the class group. It also permits to detect main motive orientation of the class (towards cognitive, creative, communicative or other types of activity).

Fixing of type and content of relations between students and a teacher at the lesson was based on a special "scheme of lesson analysis" (Rubtsov \& Ulanovskaya, 2010). It includes 31 concrete positions for fixation during the lesson (by observer) and permits to analyze lessons in three levels: content, organization, interactions.

Level of content deals with peculiarities of school subject presentation. Interactions here are analyzed from the point of view of their role in content acquisition, for example, type of questions (problem question or concrete one), number of questions, who is the initiator of questions (students or teacher), etc.

Organization level characterizes the way in which a concrete teacher solves content problems. It shows how the teacher reacts to the students' questions, how he instructs individual students' activity or organizes group work, how he influences group discussion, controls knowledge, etc.

Interaction level deals with ways by which a concrete teacher stimulates and motivates students' activity, puts grades, encourages and punishes students, demonstrates his personal reaction towards students' behavior and his personal style of interaction.

In order to find out "subjective" aspect of students" socialization we held contentanalysis of students' compositions on the topic "My school." We used five groups of categories: school, lessons, teachers and staff, classmates, the author about himself - all marked as positive, negative or neutral.

The third group of methods deals with evaluation of personal development. We used data of self-assessment and level of aspiration test, content-analysis of compositions, questionnaire of school anxiety.

For studying self-assessment and level of aspiration we used scaling procedure. Students evaluated their actual position (self-assessment) and desired position (level of aspiration) on five scales: intellect, communication and social norms.

Content-analysis of compositions permitted us to detect leading motives of students that determine their activity (cognitive, training, success, communication, etc.).

Questionnaire of school anxiety permits to evaluate anxiety, connected with school life. All these methods are described in detail in the book Technology for Assessing the School's Educational Environment (Rubtsov \& Ulanovskaya, 2010).

The expertise of educational environments was held in 24 schools (most of them are in Moscow). In each school we tested students of the 5th grades (graduates from junior school), average age 10,5 years old, and of the 9th grades (graduates from secondary school), average age 15,4 years old. Each of the students participated in all six test procedures. In general, 2,304 students took part in this work.

The choice of the 5th and 9th grades permitted us to evaluate differentially the influence of junior and secondary school educational environments on different aspects of development of students. This aspect was of special importance for us, because, on the one hand, most of teaching-learning programs, based on the theory of learning activity, are imple- 
mented in junior school. In secondary school they are not worked out as integral programs and are used mostly as a set of precise procedures while studying separate themes of school subjects (Ulanovskaya, Vysotskaya, \& Yanishevskaya, 2019). On the other hand, schools working basically as traditional, are forced to use some methods of developing education in secondary school, because teenagers often reject traditional training. That's why differentiation of junior and secondary schools could give us more precise results.

Determination of a type of educational environment, held on the preliminary phase of research, showed that only four schools can be treated as schools working in developing paradigm. The other 20 schools work in a traditional paradigm. These two groups of schools formed a sample for our diagnostic survey.

\section{Description and Analysis of Results}

The aim of this article is to compare quantitatively and qualitatively results demonstrated by students of schools working in developing and traditional educational paradigms.

Quantitative analysis of experimental data was based on SPSS statistical procedures. We treated data separately for each class, for group of classes of the same age in one school, for classes of the same age in schools of the same educational paradigm and for all schools.

Qualitative analysis permits to connect results, demonstrated in tests, with concrete teaching-learning procedures used in different educational environments.

\section{Thinking and Cognitive Processes}

"Transposition" test allows to distinguish empirical and theoretical strategies of problems' solving. The number and quality of problems solved by a student permits to distinguish three empirical and four theoretical levels of mental development.

Table 1 presents number of students (in \%) using empirical or theoretical way of problems' solving in two groups of schools: group 1 - developing schools, group $2-$ other schools.

\section{Table 1}

The ratio of empirical and theoretical ways of problems' solving in schools with a developing and a traditional educational environment, \%

\begin{tabular}{ccc}
\hline \multirow{2}{*}{ Grades } & Group 1 - developing schools & Group 2 - traditional schools \\
\cline { 2 - 3 } & empirical / theoretical & empirical / theoretical \\
\hline 5th grades & $27.25 / 72.75$ & $58.95 / 41.05$ \\
9th grades & $14.60 / 85.40$ & $18.91 / 81.09$ \\
\hline
\end{tabular}

Results of "Transposition" test demonstrate that:

1. Advantage of schools with developing paradigm in theoretical thinking development in junior school is evident. 
2. Comparison of these results with data received in CFT2 test (and statistical analysis proves it) shows, that theoretical thinking development is not determined by IQ level. For example, in one of the 5th grades of developing schools' ratio of students with empirical and theoretical way of problems' solving is 5.9 to 94.1 . It means that only one student in the whole class couldn't solve "theoretical" problems. At the same time the distribution of IQ results was close to a curve of normal distribution (average - 108.9 in the interval from 95 to 137). No school of the second group (some of them are considered to be very effective and prestige) demonstrated results close to those of the developing schools.

3. In secondary school the difference in theoretical thinking development between developing and traditional educational environments is still statistically valid, though not as large, as in junior school.

4. We found out that in two schools of the second group (traditional educational environment) 9th-grade students demonstrate higher results, then in developing schools. In order to interpret these results, we compered "Transposition" test results with IQ values. We calculated the average IQ values for students, who demonstrated empirical and theoretical types of problem solving. Our hypothesis was that only in situations where students' results in "Transposition" test were higher than those expected according to their IQ values, we could treat data as a result of educational environment influence. So, in both traditional schools, mentioned above, average IQ in the 9th grades was 115 and 119, that is much higher than average IQ values for demonstrated levels of theoretical thinking. That's why we couldn't definitely treat data as a result of educational environment effectiveness.

5. "Transposition" test allows to distinguish the depth of planning and reflection as levels of theoretical thinking. According to a number of the solved problems we have allocated four levels of theoretical thinking (from the lowest 1st level to the highest 4th one). Taking all theoretical solutions as $100 \%$, results of developing schools are $21 \%-21 \%-44.5 \%-13,5 \%$. In traditional schools' distribution of results is $48 \%-26.25 \%-17.75 \%-8 \%$. It means that students of the 9th grades in developing schools demonstrate a much higher level of theoretical thinking development than students of other schools.

6. Cognitive development results in schools of the first group are quite predictable, because one of the main teaching goals in the theory of learning activity is to help students to work out a theoretical approach (general method) to the situations of solving precise learning problems. That's why the results prove that these schools effectively use their educational technologies.

7. On the other hand, the data obtained show that various teaching methods and procedures used in schools of the second group can not give a result in thinking development compared to the effectiveness of the learning activity technology. 


\section{Social Development}

In sociometrical procedure we asked students to make choices of their classmates on general criterion, learning criterion, communicative and emotional criteria. No more than five choices were permitted.

Results of the sociometrical procedure show:

1. In developing schools (group 1) the structure of interpersonal relations in class groups is much more ramified than in schools of group 2. It means that students' interactions are more intensive. There are no restricted groups.

2. In schools of group 1 the gap in number of choices between the leaders and other students is much less than in schools of group 2. Even choices on learning criterion include middling students as well as students with excellent marks.

3. In traditional schools (group 2) the gap between the leaders and "average" students is very high and the number of leaders in the class group is limited by two or three students.

4. In schools of group 1 every student is chosen at least on one of the criteria. It means that there are no totally isolated students and each student is included into the system of interpersonal relations. In schools of group 2 in $97.5 \%$ of classes there are totally isolated students.

5. Correlation between choices was made according to different criteria differs (a) in schools with different educational environments and (b) in junior and secondary school.

6. In schools of group 1:

- learning and emotional choices coincide in $60 \%$ in the 5th grades and in $32 \%$ in the 9 th grades. And only about $25 \%$ of learning and emotional choices coincide with choices made on general criterion (both in the 5th and 9th grades). It means that in school with developing educational environment students have different and productive experience of interactions. That's why all students are included into different systems of preferences;

- in no class a business leader is isolated on emotional criterion. It means that learning results are highly appreciated in these schools.

7. In schools of group 2 :

- in the 5th grades learning and emotional choices coincide in $87 \%$, and the choices are strictly determined by students' learning success;

- both learning and emotional choices coincide with choices made according to general criterion;

- in the 9th grades results present two alternative tendencies: in five schools learning and emotional choices coincide in $59 \%$ and learning and general choices coincide in $77 \%$ (the same tendencies as in junior school), and in 15 schools business and emotional choices coincide in $14 \%$ and some of the learning leaders become emotionally isolated. It means that success in learning stops being important for success in interpersonal relations and even prevents it. Business and general choices coincide in $9 \%$ and emotional and general choices coincide in $71 \%$. 
In general, sociometrical results demonstrate effectiveness of developing educational technologies (practice in learning interaction, experience in group work) in creation of a wide network of stable and productive interpersonal relations.

Analysis of students-teacher interactions show that:

1. In schools of group 1 interactions are much more intensive: we fixed 101 units of interactions per lesson in the 5th grades and 79 in the 9th grades. In schools of group 2-24 and 37 units.

2. Interactions are qualitatively and functionally different: in schools of group 1 most of interactions deal with content and organization of learning activity; in schools of group 2 interactions mostly deal with organization of students' work (teacher's commands) and interpersonal relations (reproves and evaluation of results).

3. Evaluation is a very important part of teacher-students interactions. That's why in "the scheme of lesson analysis" we fixed different types of evaluations: aimed at personal features of a student or at his work; positive and negative. In schools of group 1 we fixed 7.2 times less number of evaluations, than in schools of group $2 ; 92 \%$ of all evaluations were aimed at the content and result of students' work and $97 \%$ of evaluations were positive. It doesn't mean, that a teacher evaluates positively mistakes or wrong results. It means, that he/she uses other procedures. For example, the teacher asks the other students questions whether they agree or can suggest another way of problem solving. Only in schools of group 1 we fixed practice of self-assessment of students according to criteria suggested by a teacher or students themselves. In schools of group 2 evaluation tremendously differs: we fixed from 2 to 76 marks for one lesson. But in general, a number of negative evaluations is higher than positive ones, and a number of "personal" evaluations is higher than a number of "work" evaluations.

As we mentioned above, subjective aspect of socialization was treated according to the results of content-analysis of students' compositions. Texts of compositions provide interesting information about different aspects of school environment.

In short, results of content-analysis of compositions show, that:

1. In schools of group 1 students' attitude towards school, teachers, lessons and schoolmates is much more differentiated than in schools of group 2. For example, in the texts of 5th-grade students gaps in their attitude towards a teacher and lessons of that teacher were fixed many times. And what is more, they try to analyze and explain their attitude. In schools of group 2 students of the 5th grades didn't distinguish these aspects ("I like drawing, because our teacher is very kind and always puts me good marks").

2. In schools of group 1 compositions include a lot of critical remarks (negative evaluations of concrete aspects of school life), but their general attitude towards school in $96 \%$ of compositions is highly positive ("I really love my school"). In schools of group 2 we got a great diversity in results. For example, in three schools more than a half of 9th-grade students didn't mention lessons in their compositions and their attitude towards school correlated with relations with 
their classmates. In six schools' attitude of 9th-grade students towards school is absolutely impersonal, based on formal criteria like "close to home" or prestigious factors like "Anyone would be proud of becoming a student of this school." In general, compositions of students in schools of group 2 are less reflective. Their judgments are more categorical (either "like" or "dislike").

In general, results prove that developing education is effective not only in the aspect of cognitive development, but also in socialization of students. The main mechanisms of social development used in developing schools are: joint forms of learning activity; intensive interactions of students and teacher initiated by teachers as well as students themselves; transfer of analysis processes, reflection and evaluation, formed in learning activity, to social sphere to analyze social relations.

\section{Personal Development}

Results of self-assessment and level of aspiration test permit us to make the following conclusions:

1. In schools of group 1 :

— in the 5th grades $88 \%$ of students demonstrate adequate self-assessment on all the scales. Self-assessments are differentiated (different marks in different scales). Level of aspiration of all the students is higher than self-assessment and the largest gap is on "friendship" scale. $62 \%$ of students demonstrate the highest level of aspiration on "friendship" scale and $71 \%$ - on "good student" scale;

— in the 9th grades $92 \%$ of students demonstrate adequate self-assessment on all the scales. Self-assessments are more differentiated than in the 5th grades. Level of aspiration of all the students is higher than self-assessment on scales of intellect and "friendship" and the largest gap is on scales of intellect. $21 \%$ of students are satisfied with their communication skills and $27 \%$ have the same meanings of self-assessment and level of aspiration on "good student" scale. Nobody demonstrated the highest level of aspiration on any scale.

2. In schools of group 2:

- in the 5th grades $43 \%$ of students demonstrate adequate self-assessment on all the scales. Self-assessments on different scales are very close. Level of aspiration of all students is higher than self-assessment and the largest gap is on "good student" scale. $62 \%$ of students demonstrate the highest level of aspiration on all scales and all the students demonstrate the highest level at least on one scale;

- in the 9 th grades $64 \%$ of students demonstrate adequate self-assessment on all the scales. Self-assessments are more differentiated than in the 5th grades. Level of aspiration of all students is higher than self-assessment on intellect scales. The most contradictory data were on "good student" scale: in four schools about $56 \%$ of students have the same meanings of self-assessment and level of aspiration on "good student" scale; in six schools we received the largest gap between self-assessment (very low) and level of aspiration (very high) on this scale. $22 \%$ demonstrated the highest level of aspiration at least on one scale. 
In general, results show that developing educational environment permits students (even in junior school) to "be satisfied" with their personal and social features and abilities, on the one hand, and to put real goals and perspectives for personal development (level of aspiration), on the other.

Questionnaire of school anxiety includes two main scales: (a) emotional stability and (b) cognitive interests. It permits to distinguish five levels of anxiety, connected with school life. Levels 1 and 2 characterize positive attitude, emotional stability and cognitive interests. Level 3 means neutral attitude towards school, unstable emotions and cognitive interests. Levels 4 and 5 mean negative emotional reactions, intensive anxiety and absence of cognitive interests.

Results of school anxiety measuring are given in Table 2.

Table 2

Levels of school anxiety in schools with developing and traditional types of educational environment, $\%$

\begin{tabular}{llcc}
\hline \multirow{2}{*}{ Group } & Grades & Emotional stability & Cognitive interests \\
\cline { 3 - 4 } & & levels & $\begin{array}{c}\text { levels } \\
\end{array}$ \\
\cline { 3 - 4 } & 5th grades & $46 / 34 / 16 / 4 /-$ & $54 / 34 / 11 / 1 /-$ \\
Group 1 & (1 / $/ 2 / 3 / 4 / 5)$ \\
(developing schools) & 9th grades & $33 / 50 / 11 / 6 /-$ & $26 / 61 / 10 / 3 /-$ \\
Group 2 & 5th grades & $4 / 42 / 31 / 16 / 7$ & $9 / 24 / 52 / 5 / 10$ \\
(traditional schools) & 9th grades & $17 / 27 / 40 / 7 / 9$ & $12 / 33 / 46 / 1 / 8$ \\
\hline
\end{tabular}

Data, presented in table 2, shows that:

1. In developing schools (group 1):

- for $80 \%$ of students of the 5th grades and for $83 \%$ of students of the 9 th grades school is associated with positive emotions. And only for $4 \%$ and $6 \%$ of students different school situations correlate with negative emotions;

$-88 \%$ of students of the 5 th grades and $87 \%$ of students of the 9 th grades demonstrate stable cognitive interests. Only $11 \%$ and $10 \%$ of students, respectively, demonstrate cognitive activity in separate learning situations (for example, at precise lessons or with precise teachers) and absence of cognitive interests in other situations.

2. In traditional schools (group 2):

- in general, less than a half of students of the 5th grades (46\%) and of the 9th grades $(44 \%)$ have stable positive attitude towards different school situations. But this data differs significantly from school to school;

- in general, cognitive interests are low both in the 5th and in the 9th grades. But these results differ in different schools significantly. There are some traditional schools where students demonstrate high and stable cognitive interests. 
3. These results correlate with data of analysis of students' compositions. In schools of group 1:

- more than a half of the students of the 9th grades mention that they do not hurry to leave school after classes (emotional comfort);

- describing the lessons $92 \%$ of students in the 5th grades and $70 \%$ in the 9 th grades use a category "interesting"; and $62 \%$ in the 5th grades and $72 \%$ in the 9 th grades use categories "useful" and "necessary";

- only $7 \%$ of students in the 5 th grades and $22 \%$ in the 9 th grades mention marks and evaluations, describing lessons or relations with teachers.

In schools of group 2 we found different expressions of the level of emotional comfort at school, but in $32 \%$ of compositions in the 5th grades and $52 \%$ in the 9th grades students discuss marks using categories "unjust" and "too strict" that demonstrate their anxiety and dissatisfaction.

\section{Discussion of Results}

Results we received in measuring thinking development were rather unexpected. In the theory of learning activity, that is used as a basis in creation of developing educational environments, the construction of problem situations, in which a student discovers a general (theoretical) method of problem-solving is one of the major teaching technologies. The main direction in critics of this theory is that it deals with scientific knowledge rather than other aspects of students' development. That's why it was important to evaluate and compare characteristics of social and personal development using traditional procedures regardless of precise educational technologies. Our results show that in developing schools social and personal development of students doesn't happen spontaneously, independently of educational influence. Analysis, reflection, experience in learning interactions and group work are used by students not only in the sphere of learning problem-solving, but also in construction and analysis of social interactions and self-assessment.

\section{References}

Davydov, V. V. (1996). Theory of developing teaching-learning process. Moscow: Intor. [In Russian] Davydov, V. V., \& Rubtsov, V. V. (Eds.). (1995). Development of the basics of reflective thinking of schoolchildren in the process of learning activity. Novosibirsk: Psychological Institute. [In Russian]

Davydov, V. V., Slobodchikov, V. I., \& Zuckerman, G. A. (1992). The younger student as an agent of learning activity. Questions of Psychology, 3-4, 14-19. [In Russian]

Elkonin, D. B. (1974). The psychology of teaching a younger student. Moscow: Znanie. [In Russian]

Elkonin, D. B., \& Davydov, V. V. (Eds.). (1962). Psychology issues of learning activity of elementary school students. Moscow: Acad. Ped. Sciences of the RSFSR. [In Russian] 
From joint activity to the construction of new social communities: Jointness. Creativity. Education. School (Roundtable of the methodological seminar supervised by V. V. Rubtsov and B. D. Elkonin). (2018). Cultural-Historical Psychology, 14(3), 5-30. https://doi.org/10.17759/chp.2018140301 [In Russian]

Leontyev, A. N. (1981). Problems of the development of the mind (4th ed.). Moscow: MSU. [In Russian] Polivanova, N. I., Rivina, I. V., \& Ulanovskaya, I. M. (2017). The system of developing teachinglearning activity as a factor in the formation of communicative skills in primary school students. In: G. G. Kravtsov (Ed.), Theory and practice of cultural and historical psychology: Materials of the XVIII International readings in memory of L. S. Vygotsky (pt. 1, pp. 157-163). Moscow: Lev, 2017. [In Russian]

Rubtsov, V. V., \& Ivoshina, T. G. (2002). Designing the learning environment of the school. Moscow: MSUPE. [In Russian]

Rubtsov, V. V., \& Polivanova, N. I. (Eds.). (2007). The educational environment of the school as a factor of psychological development of students. Moscow, Obninsk: IG-SOTSIN. [In Russian]

Rubtsov, V. V., \& Ulanovskaya, I. M. (Eds.). (2010). Technology for assessing the school's educational environment. Moscow, Obninsk: IG-SOTSIN. [In Russian]

Ulanovskaya, I. M., Polivanova, N. I., \& Ermakova, I. V. (1998). School's educational environment: What does it mean and how to detect it? Questions of Psychology, 6, 18-24. [In Russian]

Ulanovskaya, I., Vysotskaya, E., \& Yanishevskaya, M. (2019). Formation of meta-subject competencies by means of school subjects [Abstract]. In Book of abstract: XVI European Congress of Psychology (ECP 2019) (p. 1784). Moscow: Moscow University Press. Retrieved from https://ecp2019.ru>doc>Book_of_Abstracts_ecp_2019

Zak, A. (2019a). Formation of reflection and development of critical thinking in modern junior school. In T. Martsinkovskaya \& V. Orestova (Eds.), PSYRGGU 2019 - Psychology of subculture: Phenomenology and contemporary tendencies of development. The European Proceedings of Social \& Behavioural Sciences EpSBS, LXIV, 778-784. Retrieved from https://www.futureacademy.org.uk/files/images/upload/PSYRGGU2019F101.pdf

Zak, A. Z. (2019b). The conditions for the formation of intellectual actions in fourth graders. Education and Science in Russia and Abroad, 50(2), 102-111. [In Russian]

Original manuscript received June 04, 2020 Revised manuscript accepted August 17, 2020

First published online November 13, 2020

To cite this article: Rubtsov, V. V., \& Ulanovskaya, I. M. (2020). Educational environment and indicators of child development. Lurian Journal, 1(2), 71-84. doi: 10.15826/Lurian.2020.1.2.6 